Vol. LXVII 2015

\title{
RESULTS REGARD PRODUCTIVITY OF SOME QUINCE VARIETIES CULTIVATED IN NORTHERN OLTENIA AREA DEPENDING OF THE ARHITECTURAL ELEMENTS OF THE TREES CROWN
}

\author{
Ph.D.Croitoru Dorin Cătălin \\ Ph.D.Ing., Horticultural Research and Development Station Tagu Jiu, Romania \\ E-mail: pomicola@intergorj.ro \\ Prof .Univ.Dr.Ing..Baciu Aurelian Adrian \\ Professor,Universitatea din Craiova (University of Craiova), Craiova, Romania \\ E-mail: aurelian.adrian@gmail.com \\ Dr.Ing.Pătraşcu Bianca Ionela \\ Horticultural Research and Development Station Targu Jiu, Romania \\ E-mail: pomicola@intergorj.ro
}

\begin{abstract}
Experimental area is located on the third terrace of the Jiu River at the altitude of $383 \mathrm{~m}$ in the northern part of Targu-Jiu City on the experimental plantations established in 1987 at Targu-Jiu Fruit-Growing Research and Production Station.Considering the favourable area of the quince culture in Northern Oltenia an experience was placed under the conditions for intensive plantations for zoned varieties. The variety and crown shape are important factors in the intensive cultivation of quince. The experience was placed after the subdivided parcels method with two factors being the type $4 \times 5$ in three repetitions. The studied factors:- Factor - shaped crown with four graduations - late flat bowl, simple palm, shapeless hedge, bush trunk - Factor B - 5 varieties of quince graduations Aurii, Aromate, Moldoveneşti, De Constantinopol, De Portugalia Results obtained in the three years of study 2012 - 2014 emphasize the superiority of crown shape and variety Moldoveneşti vessel flattened late in terms of quantity and quality of fruit.
\end{abstract}

Key words: words: quince, crown shape, variety, productivity

\section{Introduction}

Quince is a rustic specie with a high adaptability to climatic conditions, therefore with a wide spread area in our country, as well as with a high quality of the fruit which represents the valuable raw material for processing. [1, 3, 4].

The important position the quince occupied in ancient peoples, tree growing has gradually decreased, as there have been developed other species, particularly the apple and the pear as a result of their better taste qualities and characteristics of being kept fresh for consuming for a longer period of time after harvest. [2].

Quince range is generally provided insufficient varieties to ensure the requirements of a modern fruit growing, especially in terms of tolerance to major diseases of trees habitus, size, shape and quality of the fruit.

Within Tg-Jiu Horticulture Research - Development Station there have been and there still are l concerns regarding the production improvement and check of some valuable quinces varieties and biotypes, as well as the establishment of modern technological links specific to this culture. [6, 7].

Considering the favourable area of the quince culture in Northern Oltenia an experience was placed under the conditions for intensive plantations for zoned varieties.

Experimental area is located on the third terrace of the Jiu River at the altitude of $383 \mathrm{~m}$ in the northern part of Targu-Jiu City on the experimental plantations established in 1987 at Targu-Jiu FruitGrowing Research and Production Station.

The soil type is albic luvisol, pseudogleized with a percentage of up to $30 \%$ natural clay with low permeability, existing the danger of bogging while excessive rainfall, poorly stocked in nutrients, the depth of groundwater being of 1 to $1.5 \mathrm{~m}$, weakly acid soil reaction. 
The area is included in a temperate climate with an annual average temperature of 10,20 C and an annual average volume of precipitation of $753 \mathrm{~mm}$, unevenly distributed in the course of the year. [8].

\section{Material and methods}

Agro-technical works were applied according to the technological record of this culture, in all variants, as a common factor, the spaces between rows were grassed, repeatedly mowed, the resulted organic material used as a straw cover along the rows.

The bear fruit - fructification cutting were applied differently according to each experimental variant, aiming to achieve well-balanced and trimmed crowns .

An important factor in intensive quince cultures is the crown shape, with influence on the quantity and quality of the production and especially on the disease attack, mainly Erwinia amylovora and Monilii [5].

Setting the crown shape involves the lowest cost for cutting maintenance and harvesting, all these having as final goal the getting constant and effective annual productions.

Therefore, there have been studied the following factors: Portugalia

Factor A: - The 5 stages variety, namely: Aurii, Aromate, Moldoveneşti, De Constantinopol, De

Factor B - Crown shaped with 4 stages: late flat bowl, simple palm, bush trunk, shapeless hedge.

\section{Results and discussions}

\section{Results regarding fruit production}

The fruit production obtained depending on the shape crown and variety of the quince

Data recorded in the study period of 2012-2014 highlight a relatively constant production, with two propitious years 2012 and 2013 and a year, 2014, with a slightly diminished fruit production as a result of the influence of the unfavourable climatic conditions.

Average the of the three years ranks the quince production at a level characteristic of the study area, but not at the maximum potential of the variety.

Importantly is that the studied factors constituted a technological factor essential in the differentiation of the fruit production.

So, the crown shape is important as technological link in the quince culture.

The statistics revealed the contribution of the Late flat bowl shape crown to the assurance of some production increases distinct significantly positive, respectively 2,0 tones/ha, followed by the Shapeless hedge shape crown with 1,99 tones/ha.

These increases are statistically ensured which give the stability to these shape crowns in assurance of some superior productions of other shape crowns, respectively Simple palm and Bush trunk.

The quince variety represents another technological element in getting some safe and constant productions. The data recorded in the study period revealed the superior and constant production of the Moldovenești and De Constantinopol variety.

Productions of 22,07 tones/ha and respectively, of 20,44 tones/ha represent, actually, an increase of 4,15 tones/ha, and respectively 2,52 tones/ha, very significantly positive to the witness, respectively, De Portugalia variety .

Analising the combined influence of the factors crown shape $\mathrm{x}$ variety to the quince production, the following condition can be drawn (table no.1).

the Late flat bowl shape crown ensures distinct and very significantly positive increases at the Moldovenești, Aurii and De Constantinopol varieties. These increases are between tones/ha and 3,4 tones/ha to the witness variety De Portugalia.

the Moldovenești variety is a variety with a plasticity adaptable increased to the other crown shapes, too, which ensures increases distinct, significantly positive for the others crown shapes, with production increases between 3,6 to/ha Shapeless hedge shape crown up to 4,0 to/ha Simple palm shape crown.

To conclude,the Moldovenesti variety is a variety representative of the study area, the recomanded crown shape being the Late flat bowl, superior to others crown shapes, even if these ensure production increases distinct significantly positive. 


\section{Fig.1.The detail regarding the fruit number of Moldoveneşti}

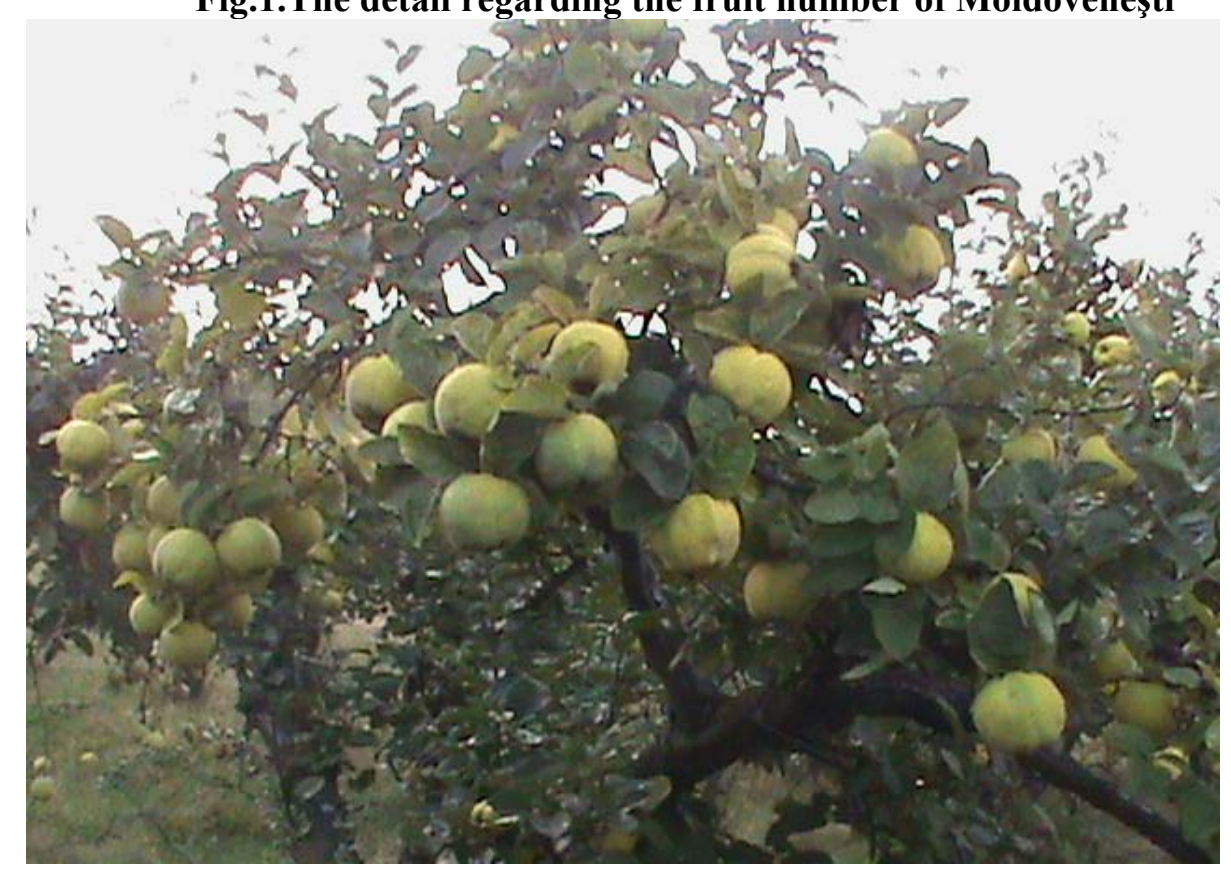

\section{Quince productivity reported in the crown volume}

The crown volume represents an important factor in evaluating the fruit production, depending on which will be adopted the crown shape, the plantation density.

Depending on the three measured dimensions: length, width, height, it was set the crown volume reported at the crown shape and at the variety.

The determinations were made at the end of the vegetation period, after the fruit harvest, biological particularities of the variety represented an essential factor in the crown volume.

De Portugalia and De Constantinopol variety stands out with a crown volume of $29 \mathrm{mc} / \mathrm{plant}$ and $35 \mathrm{mc} /$ plant at the plantation in classic system of 625 plants/ha and of $19 \mathrm{mc} /$ plant up to $23 \mathrm{mc} / \mathrm{plant}$ at the plantation in the intensive system of 1250 plants/ha.

Close values were determinated at the Aromate and Aurii varieties, varieties with a medium force. At the Moldovenesti variety, the measured parameters lead to a smaller crown volume from the other studied varieties.

At this variety, the crown volum was in the limits of $15 \mathrm{mc} /$ tree at Shapeless hedge and Bush trunk and of 24, $81 \mathrm{mc} /$ plant at the Late flat bowl crown and of 21,11 mc/plant at the Simple Palm shape crown.

A review of the influence of the crown shape on the crown volume concluded that at the Late flat bowl shape crown it was achieved a crown volume of 29,81 mc/plant, followed by the Simple Palm shape crown with 27,34 mc/plant. The Bush trunk and Shapeless hedge crown shapes practiced in the intensive system of 1250 trees/ha represented a crown volume of 19,05 mc/plant, respectively, 18,08 mc/plant.

Reporting the influence of the crown shape (table no.2 ) to the Shapeless witness, it stands out an increase of $66 \%$ (19,9 mc/plant) at the Late flat bowl shape-increase very significantly positive, followed by the Simple palm shape with an increase of $52 \%$, respectively $9,4 \mathrm{mc} /$ plant, in addition.

With reference of the quince variety, from the table no. 3 , it concludes that the De Portugalia and De Constantinopol varieties present a large force compared with the Aromate , Aurii and Moldovenesti varieties.

Differences , less than the witness variety - the De Portugalia variety, were of $-8,9 \mathrm{mc} / \mathrm{plant}$ at the Moldovenesti variety , $-6,3 \mathrm{mc} / \mathrm{plant}$ at Aurii variety and of $-4,9 \mathrm{mc} / \mathrm{plant}$ at Aromate varieties, increases very significantly negative.

The combined influence of the factors of the shaped crown varieties on the crown volume outlines negative differences of the Moldovenesti variety to De Portugalia witness variety, the maximum value being of $-11,7 \mathrm{mc} /$ plant at the Simple palm shape crown.

These data hidhlight, actually, the weak to medium force of the Moldovenesti variety, but with a large potential of fructification. Also, between shaped crowns, at the same variety, there are differences which highlight, in weight, the superiority of the Late flate bowl and of Simple palm shape crown, with classic densities of plantation of 625 plant/ha. 
Table no. 2

The influence of the crown shape and volume of the quince, Targu-Jiu, 2012 - 2014

\begin{tabular}{|l|c|c|c|c|}
\hline \multirow{2}{*}{ Crown shape } & \multicolumn{2}{|c|}{ The volume of crown } & \multirow{2}{*}{$\begin{array}{c}\text { The difference } \\
\text { mc./tree }\end{array}$} & The significance \\
\cline { 2 - 3 } & mc. & $\mathbf{\%}$ & 11,9 & $\mathrm{xxx}$ \\
\hline Late Flat Bowl & 29,8 & 166 & 9,4 & $\mathrm{xx}$ \\
\hline Simple Palm & 27,3 & 152 & 1,2 & - \\
\hline Bush Trunk & 19,1 & 106 & Mt. & - \\
\hline Shapeless Hedge & 17,9 & 100 & & - \\
\hline
\end{tabular}

DL $5 \%=1,87 \times 2,45=4,58 \mathrm{mc} . / \mathrm{pom}$

DL $1 \%=1,87 \times 3,71=6,94 \mathrm{mc} . / \mathrm{pom}$

DL $0,1 \%=1,87 \times 5,96=11,15$ mc./pom

Table no. 3

The influence of the variety on the crown volume on quince, Tg-Jiu, 2012 - 2014

\begin{tabular}{|l|c|c|c|c|}
\hline \multirow{2}{*}{ Variety } & \multicolumn{2}{|c|}{ The volume of crown } & \multirow{2}{*}{$\begin{array}{c}\text { The difference } \\
\text { mc./tree }\end{array}$} & The significance \\
\cline { 2 - 4 } & mc. & $\mathbf{\%}$ & $-4,9$ & 00 \\
\hline Aromate & 23,1 & 82,5 & $-6,3$ & 000 \\
\hline Aurii & 21,7 & 77,5 & $-8,9$ & 000 \\
\hline Moldoveneşti & 19,1 & 68,2 & $-2,3$ & - \\
\hline De Constantinopol & 25,7 & 91,7 & Mt. & - \\
\hline De Portugalia & 28,0 & 100 & & \\
\hline
\end{tabular}

DL $5 \%=1,48 \times 2,04=3,02 \mathrm{mc} . / \mathrm{pom}$

DL $1 \%=1,48 \times 2,75=4,07 \mathrm{mc} . / \mathrm{pom}$

DL $0,1 \%=1,48 \times 3,65=5,40 \mathrm{mc} . / \mathrm{pom}$

\section{Quince productivity reported to nutrition area}

Nutrition area is an essential factor to ensure the optimal conditions for the growth and development of the plants, respectively, the fruit production, their quality.

Of specialty literature was concluded that at the intensive and superintensive plantations the natural fertility of the soil it must be boosted by a big input of technological factors comparing to the classic formulas.

Reporting the fruit production to the nutrition area created in the experience by practising of the two planting densities, of 625 trees/ha and of 1250 trees/ha it finds significant differences between these (table no 4.)

Thus, the high density of 1250 trees/ha offers a small nutrition place to the plant, of $8 \mathrm{mp}$ and achieved the lowest productions, respectively of $16,62 \mathrm{~kg} / 8 \mathrm{~m}$ at the Shapeless hedge and of 15,03 $\mathrm{Kg} / 8$ $\mathrm{m}$ at the Bush trunk shape crown.

Compared to this density, the practice of the culture of 625 plants/ha, respectively a double nutrition area of $16 \mathrm{mp}$, it was materialized in a 30,3 Kg/16 m at the Simple palm shape crown.

Regarding the studied varieties it results that the Moldovenesti variety capitalized better the nutrition area both at 625 trees/ha density and at 1250 trees /ha density.

It is the variety which from the point of view of the corelation with other indicators is superior than other studied varieties.

The projection of the crown is a ,shade,, of the crown volume, so between the two attributes there is a direct correlation .

In this context, the varieties with a large force De Constantinopol and De Portugalia were expressed in a crown projection up to $11,48 \mathrm{mp}$ at the Simple palm and to $10,8 \mathrm{mp}$ at the Late flat bowl shape crown.

In terms of productivity reported to the nutrition area, optimum was the 625 trees/ha, option, with Simple palm or Late flat bowl shape crown using Moldovenesti variety with a production level of 37,49 Kg/16 mp,respectively 33,43 kg/16 mp.(Table no.4).

Reporting the nutrition area to the fruit production achieved by a single tree and by the surface unit, it concluded that at high densities of 1250 trees/ha there is the tendency that the fruit to be qualitative affected, respectively the fruit weight and even the qualitative indicators, the acidity, vitamin C, dried substance, etc.

It is created a competition at the root system which, in the low fertility conditions and in the lack of moisture, the production is quantitative and qualitative affected.

The solution should be the irrigation respectively, the fertilization, especially in the critical period of fruit growth. 
Following the soil humidity dynamics it was found that, also in the Oltenia hilly area, on these bed luvisoils with poor hydric regime, in July and August appears the drought and, so, the drip irigation would be appropiate.So, the nutrients being in the nutrition area, would be easier solubilized and assimilated by the plant.

Quince productivity according to nutrition space, Tg.-Jiu, 2012 - 2014

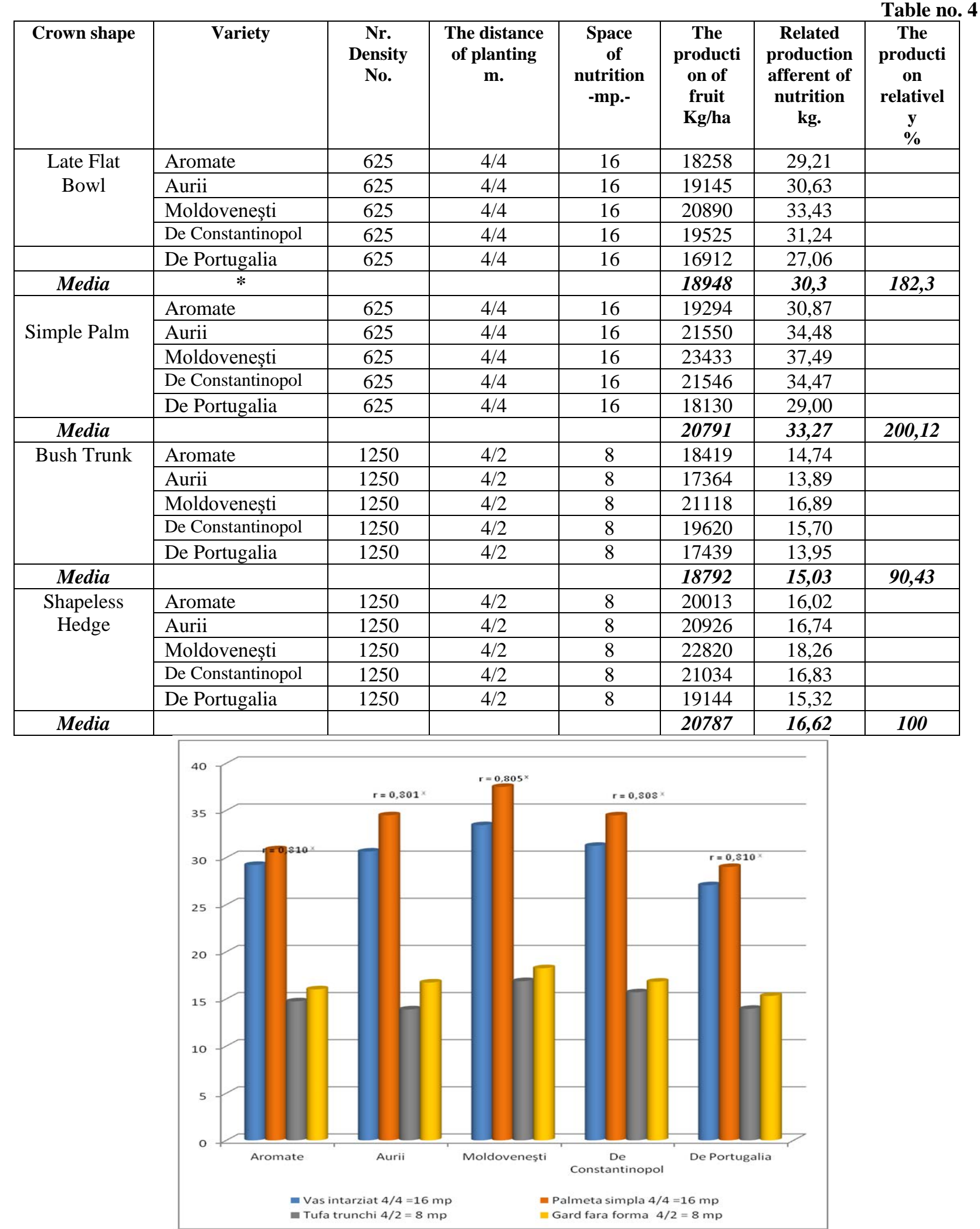

Fig.2.The quince productivity according to de nutrition space, average $\mathrm{kg} / \mathrm{mc}$ crown shape and variety, $\mathrm{Tg}$ 


\section{Quince productivity reported to crown projection}

By increasing of the density at the same varieties, it was reduced the crown projection under 7,11 mp ,,The Aurii, Aromate, Moldovenesti,, varieties recorded a crown projection between 6,14 mp at Bush trunk up to 10,37 mp at Simple palm shape crown.

Reporting the crown projection at the nutrition area it results that between these two elements there is a overlap.

Based on the determinations of the crown dimensions, respectively length and width, it finds that at the Late flat bowl shape crown, the crown projection is a rectangle, 3,81 $\mathrm{m}$ x 2,75 $\mathrm{m}$ which represents a report of 1,4:1 between sides.

At the Simple palm shape crown, the rectangular sides are 3,78 $\mathrm{m}$ x 2,58m, respectively, a report of $1,47: 1$, so a slight reduction of the crown width.

At the bush trunk and shapeless hedge shape crown, the dimensions of the two sides are aproximatively, equals, respectively $2,85 \mathrm{~m} \times 2,49 \mathrm{~m}$ and 2,79 $\mathrm{m} \times 2,49 \mathrm{~m}$, the side report beeing of $1,14: 1$, respectively $1,12: 1$. There are essential elements at the establishment of quince plantation, of the plantation system, so to be avoided the shading, but also, the access of the equipments to do maintenance works.

So, if at a 625 plants/ha density plants at $4 \mathrm{~m} \mathrm{x} 4 \mathrm{~m}$, it results that the crown of two neighbour trees do not overlap, there being even free space which ease the equipment movement, and ensures a „,coridor,, for ventilation, airing and the penetration of light and heat.

\section{Conclusions and recommendations}

Based on the studies of the 2012-2014 period reffering to the agroproductivity of some quince varieties in the Oltenia hilly area, it is recommended:

1) The practice of the quince culture in intensive plantations with a density of 625 plants/ha, respectively $4 \mathrm{~m} \times 4 \mathrm{~m}$.

2) The use in the culture of the area quince varieties, respectively Moldovenesti, Aromate and Aurii varieties

3) The adaptation of the Late flat bowl shape crown, crown which allows a good airing of plantation, the penetration of the light and heat, factors which attenuates the infection with Monilia species and with Erwinia amylovora, diseases very dangerous in the last years at the quinces, which can compromise completely the quince production.

\section{References}

1. Badescu Gh., Constantinescu M., Badescu Lidia, Isac Gh., Fructele şi sanatatea. Editura Ceres, Bucuresti, p. 78, (1984)

2. Caliopi R., The Quince , Editura Ceres, Bucharest, p. 5, 6, (1972)

3. Cepoiu Nicolae, Pomicultura aplicată, Editura Ştiinţelor Agricole Bucureşti, pag.173, (2001)

4. Draganescu E., Fructele Terrei, alimente, medicamente, cosmetice. Editura Mirton, Timisoara, p. 215-222, (2006)

5. Gosch, C., Fischer , T.C., Stich, K., Moosbeckhofer, R., Reisenzein , H. and Persen, UNew bactericides against fire blight (Erwinia amylovora) and development of a fast bee- Erwinia monitoring system. Acta Hort. (ISHS) 917:139-142, (2011)

6. I.Roman - 1994,35 de ani de activitate a Staţiunea de Cercetare şi Producţie Pomicolă Tg.Jiu, Comportarea unor soiuri noi de gutui în condiţiile de la Staţiunea de Cercetare şi Producţie Pomicolă Tg.-Jiu, pag.82-85, (1994)

7. I.Roman, Tomescu I, Paducel C.,35 ani de activitatea ai Staţiunii de Cercetare şi Productie Pomicolă Tg.-Jiu Selecţii şi soiuri de gutui create la Tg.-Jiu, pag.77 - 81(1994)

8. Nicolae Ghenea, Nicolae Branişte, Cultura specială a pomilor, Editura Matrix Rom Bucureşti, pag.39, (2003). 